but whence do they themselves originate? And this question still remains unsolved. The polyps are observed to increase by budding, but they never form clusters of more than four "persons." How do they become distributed over the under surface of nearly all the floating leaves in the tank? How do they get carried to an outside reservoir? Is it not improbable that they would continue year after year to propagate themselves by budding as polyps, and in the summer to throw off successive crops of male medusæ? It is possible that this is the whole history, but not quite probable.

In any case, however, the existence of the minute polyps attached to water-plants is sufficient to explain the introduction of the jelly-fish to Sheffield. It also is sufficient to explain the original introduction of the jellyfish to the Regent's Park, since in 1878 (two years before the first discovery of the jelly-fish) specimens of a remarkable water-plant (Pontederia) were brought from Brazil by a lady and presented to the Botanical Society, and placed in the Victoria Regia tank.

A new interest has recently been added to that already attaching to Limnocodium by the description of another fresh-water jelly-fish, the Limnocnida Tanganyisice. This remarkable form was worked out in my laboratory in Oxford during last winter by Mr. R. T. Günther, who received the specimens from his father, Dr. Günther, F.R.S., of the British Museum. Dr. Günther had written to the Mission on Lake Tanganyika in order to procure the specimens. Individuals of three kinds are described by Mr. Günther, viz. males, females, and a-sexual individuals which produce crops of buds on the manubrium (see his papers in the Ann. and Mag. Nat. Hist., I893, and in the forthcoming number of the Quart.Journ. Micros. Science). Whilst differing greatly from Limnocodium in most respects, Limnocnida agrees with it, in a most extraordinary way, in the minute structure of the marginal sense-organs. No light is thrown by Limnocnida on the problem of the life-history of Limnocodium.

I subjoin a list of dates in reference to the history of Limnocodium, and may add that the columns of NATURE already contain numerovs communications relative to it, viz. in vol. xxii. (1880), pp. 147, 177, 178, 190, 218 , $24 \mathrm{r}, 290$, and in vol. xxxi. p. 107.

I880.-June ro, first observed in Regent's Park; remained six weeks.

I881.- June I2; reappeared; remained five weeks.

1882. - None observed.

I883.-April 28; twelve weeks.

1884. -April 27; twelve weeks (?).

1885. - April 5 (no record of duration).

1886. - August 7 (no record of duration)

1887. - End of May (no record of duration).

1888. - May Io (no record; very few observed).

I889. - None.

I890. - New tank constructed and stocked; July Io a few.

1891.- - None.

1892.- None. Plants sent to Sheffield April 4.

1893.- None in London. Plants again sent, April 7, to Sheffield.

r893.- -June 7 to mid-October, large numbers observed in tank at Sheffield.

Hydroid trophosome discovered by Bourne in winter of 1884 . Production of medusæ by hydroid, observed by Fowler, in May, 1888. E. Ray LaNKESTer.

\section{DEATH OF PROF TYNDALL.}

A NOTHER of our "Scientific Worthies" has" "crossed the bar," leaving behind an honoured name and works that will perpetuate his memory. On Monday evening Prof. Tyndall passed away at his residence, near Haslemere. For some time previous he had been suffering from insomnia and rheumatism, and very unfavourable symptoms set in on Monday morning. He quickly became unconscious, and except for a brief interval at midday, remained in this state until half-past six o'clock, when a peaceful change from life to death took place. It appears that the cause of death was an overdose of chloral, which Prof. Tyndall took as a sedative against insomnia. He had been in the habit of taking narcotics for several years past in order to overcome the sleeplessness from which he suffered. On Monday about the usual quantity was administered to him, but his greatly weakened condition was unable to bear so much. The inquest on the body, which was considered necessary by the doctors, was held yesterday.

A detailed account of Tyndall's life was given in these columns in August, 1874 , so it is only necessary to trace now a brief outline of his career. He was born in 1820 , at Leighlin Bridge, near Carlow, in Ireland. But it was not until 1847 that he began his career as a teacher of science, by accepting a post in Queenwood College, Hampshire, where Dr. Frankland was chemist. A year later the two friends did what every young man of science should do, if possible-they went together to a German University, the University of Murburg, Hesse Cassel, rendered celebrated by Bunsen and others; and to Bunsen, whose lectures he attended, and in whose laboratory he worked, Tyndall was never tired of expressing his obligations. He was at Murburg when Knoblauch, preceded by a distinguished reputation, and accompanied by a choice collection of instruments, went there as Extraordinary Professor. Subsequently, in conjunction with Knoblauch, Tyndall carried on his " classic" inquiries in connection with diamagnetism, afterwards prosecuting his research in the laboratory of Prof. Magnus at Berlin. In $185 \mathrm{I}$ his life-long friendship with Prof. Huxley commenced, and in the following year he was elected a Fellow of the Royal Society. In February, I 853 , he gave the first of his eloquent Friday evening lectures at the Royal Institution. Shortly afterwards, at the proposal of Faraday, he was appointed Professor of Physics in the Institution, a post from which he retired in I887. The managers and members of the Institution marked their sense of the benefits he had conferred upon it by electing him as Honorary Professor, a title previously borne by Davy and Brande, and by calling one of the annual courses of lectures "The Tyndall Lectures." His bust was also placed in the Institution in memory of his relations with it.

A complimentary dinner was given to Tyndall on the occasion of his retirement from the Chair of Physics in the Royal Institution. The body of eminent men which met at the dinner was such as has seldom if ever been brought together to do honour to a man of science, and when the chairman, Sir George Stokes, the then President of the Royal Society, gave voice to the desire of the company that their guest should long enjoy the leisure which he had so well earned, it was not thought that after but six years of rest from labour he would be called away. The speeches made at the dinner are reported in NATURE, vol. xxxvi. p. 222, and they show the high regard in which Tyndall was held throughout the world of science, art, and letters. In responding to the toast of the evening, he gave an account of his life, including in his speech the following true remarks:- " To keep technical education from withering, and to preserve the applications of science from decay, the roots of both of them must be imbedded in the soil of original investigation. And here let it be emphatically added, that in such investigation practical results may enter as incidents, but must never usurp the place of aims. The true son of science will pursue his inquiries irrespective of practical considerations. $\mathrm{He}$ will ever regard the acquisition and expansion of natural knowledge-the unravelling of the complex web of nature by the disciplined intellect of man, as his noblest end, and not as a means to any other end." This was the kind of spirit that actuated Tyndall throughout his career. It

NO. I 258 , VOL. 49] 
was well shown in 1872 , when he placed the balance of 13,000 dollars, that remained after his lecturing tour in the United States, in the hands of a committee who were authorised "to expend the interest in aid of students who devote themselves to original research."

It would be superfluous for us to enumerate Tyndall's explorations in the domain of science, or to expatiate upon his remarkable power of presenting a subject both in speech and in writing, for among men of science these facts are common knowledge. To such men as he-not only original discoverers, but also popular and powerful interpreters of scientific fact-we owe much of the advancement that has been made during the last forty years.

\section{NOTES}

Mr. H. H. Turner, of Greenwich Observatory, has been elected to the Savilian Professorship of Astronomy at Oxford, in succession to the late Prof. Pritchard.

THE Russian traveller Potanin, who has spent more than a twelvemonth in a botanical exploration of Thibet, is expected in St. Petersburg in January next. M. Dobrotworsky has arrived at Jenisseisk on the Jenissei, on a botanical expedition.

Prof. Ben. K. Emerson, of Amherst College, and of the U.S. Geological Survey, who met with a serious railroad accident last summer, and was reported killed, has so far recovered that he started in November on a trip round the world, for rest and recuperation. He visits Italy, Egypt, India, Java, and Japan. Prof. Emerson has been engaged for a long time in mapping the crystalline rocks of Central Massachusetts and Connecticut-

DR. NiCOLE has been appointed Director of the Bacteriological Institute of Constantinople.

DR. Seubert has been appointed Professor of Analytical and Pharmaceutical Chemistry in the University of Tübingen.

Mr. W. F. C. GurLeY has been appointed Director of the Geological Survey of Illinois.

WE learn that Prof. D. A. Gilchrist has accepted the Professorship of Agriculture at the University Extension College, Reading.

Dr. K. von Dalla Torre has been appointed Professor of Botany in the University of Innsbrück, and Dr. H. Möller Professor of Botany in the University of Greifswald.

Mr. W. T. MCGEE, known for his contributions to geology, has been appointed Director of the Bureau of Ethnology at Washington, U.S.

ThE Chair of Comparative Anatomy and Zoology in the Biological School of the University of Pennsylvania has been accepted by Prof. E. D. Cope, and that of Geology and Mineralogy by Prof. A. P. Brown.

THE death of Dr. Webb, the well-known Principal of the Aspatria Agriculture College, is a severe loss to agricultural education. After a very brief illness, he passed away on November 28 , in the prime of life. Through his exertions the College at Aspatria has been raised from a very low condition to its present high standing. He was greatly respected by his students, and his place as a teacher of agriculture will not be easily filled.

THE first step towards the introduction of the decimal system into Russia will be taken on January 13, 1894, when, by order of the Czar, the chemists of the Russian empire will begin to use decimal weights and measures.

A PRIZE of 1800 liras is offered by the Italian Geological Society for the best account of the state of knowledge of Palæozoic and Mesozoic formation in Italy, the work to be in continuation of D'Archiac's “Histoire des progrès de la Geologie," and to be presented before the end of March, 1896 .
Die Natur announces that the Berlin Academy of Sciences has granted Drs. Richarz and Krygar-Menzel two thousand marks for the carrying on of their investigations of the constant of gravitation. A like sum has been granted to Dr. Franz Reinecke for the furtherance of his ethnological and anthropological studies.

THE ninth congress of Russian Naturalists will be opened at Moscow on January 15, 1894. The Mathematical and Physical Faculty of the Moscow University has undertaken its organisation. Reductions of railway fares are offered to persons who will apply for that purpose to the Dean of the Faculty before December 13. The first general meeting of the congress will take place on January 16 , and the conference will close on the 23 rd of that month.

Mr. C. M. IRvine informs us that at four o'clock on the afternoon of December 4 a brilliant meteor passed over Lesmahagow, N.B., travelling true south. The altitude was about $45^{\circ}$. The arc through which it was visible was about $10^{\circ}$, and the duration of visibility nearly 3 secs. Colour, pale greenish blue. The sky was overcast with detached clouds. The passage of the meteor was slightly zigzag, deviating from a straight line by about $I^{\circ}$ on either side.

THE second series of lectures given by the Sunday Lecture Society begins on December 1o, in St. George's Hall, when Sir Benjamin W. Richardson, F.R.S., will lecture on "The Mastery of Pain." Lectures will subsequently be given by Prof. A. A. Rambaut, Royal Astronomer of Ireland; Dr. R. D. Roberts, Prof. Percy Frankland, F.R.S., Mr. C. T. Dent, Mr. Arthur W. Clayden, and Prof. R. Meldola, F.R.S.

THE following are among the lecture arrangements at the Royal Institution before Easter:--Prof. Dewar, six lectures (adapted to a juvenile auditory) on air, gaseous and liquid; Prof. Charles Stewart, nine lectures on locomotion and fixation in plants and animals; Mr. W. Martin Conway, three lectures on the past and future of mountain exploration; Prof. Max Müller, three lectures on the Vedânta philosophy; the Right Hon. Lord Rayleigh, six lectures on light with special reference to the optical discoveries of Newton. The Friday evening meetings will begin on January 19 , when a discourse will be given by Prof. Dewar, on scientific uses of liquid nitrogen and air. Succeeding discourses will probably be given by Mr. A. P. Graves, Mr. T. J. Cobden-Sanderson, Prof. W. F. R. Weldon, Prof. Silvanus P. Thompson, Prof. John G. McKendrick, Dr. W. H. White, the Right Hon. Lord Rayleigh, and others.

According to the Times correspondent at Cairo, Messrs. Garstin and Willcocks have inspected the four sites proposed for reservoirs in which to store water for irrigation purposes during the summer when the Nile is low, and their reports will shortly be presented. The Government will then invite three European hydraulic engineers of the highest reputation to come to Egypt and make a technical examination of the proposed schemes. This will probably be in February next. Three of these schemes are for the construction of dams across the river at either Kalabsheh, Assouan, or Silsileh ; the fourth proposes to utilise the natural depression of the Wady Raian, in the province of Fayoum, by conducting into it the flood-water of the Nile.

THE London County Council some time ago decided to establish a pathological laboratory and museum in connection with the Londion lunatic asylums. Last week the Council accepted the plans prepared by Mr. G. T. Hine, and we understand that they will shortly be put into execution at Claybury. A competent pathologist is now to be appointed, who will be supplied with material from the Claybury and other asylums under the supervision of the London County Council. The necessity for

NO. 1258 , VOL. 49] 